\title{
Clinico-etiological profile and outcome of traumatic head injury in children- a tertiary care experience
}

\author{
Maheswari $\mathbf{K}^{1}$ \\ ${ }^{1}$ Dr. K. Maheswari, Assistant Professor, Department of Paediatrics, Velammal Medical College, Madurai, Tamilnadu, \\ India.
}

Address for Correspondence: Dr K. Maheswari, 3D, Thamirabarani Block, Doctors Quarters, VMCH, Madurai. E-mail of the author: maheswarijipmer@gmail.com

\begin{abstract}
Introduction: Children are most vulnerable to head injury, which is one of the most common indications for hospitalization and is often associated with significant morbidity and mortality in severe cases. This study was undertaken to know about the clinical profile, etiology and outcome of head injury in children in a tertiary care hospital. Study Design: Retrospective study. Materials and method: This study was done on 53 children with head injury admitted to pediatric department of Velammal Medical College, Madurai from October 2013- December 2016. Results: Out of the 53 children studied with head injury, males outnumbered (60.3\%) females (39.6\%). Road traffic accident was the most common cause of head injury (52.8\%), followed by accidental fall (47.1\%). Vomiting was the most common symptom at admission (58.4\%) followed by injuries to scalp and face (41.5\%) headache (37.7\%), altered sensorium $(28.3 \%)$. Head injury was mild in severity in $71.6 \%$ of childer. Neuro-imaging analysis showed traumatic brain injury in $(73.5 \%)$ of them, skull bone fractures in (49\%), facial bone fractures in (15\%) of children. Outcome was measured as with full recovery in $86.7 \%$ of children, $(5.6 \%)$ had partial recovery, death in $3.7 \%$ of children. Conclusion: Parental guidance is advised to avoid accidental falls. Implementation of strict traffic rules, timely intervention and aggressive management reduces morbidity and mortality in children with traumatic head injury.
\end{abstract}

Keywords: Mechanism; Traumatic brain injury; Skull fracture

\section{Introduction}

Traumatic Brain Injury (TBI) is defined as an acquired injury to the brain caused by an external physical force, resulting in total or partial functional disability or psychosocial impairment or both, that adversely affect a child's educational performance. The term does not apply to brain injury that are congenital, degenerative, or brain injuries induced by birth trauma. Level of consciousness is the most common and reliable clinical parameter used for evaluating brain injury severity.

The most widely used measure of level of consciousness is the Glascow Coma Scale [1]. TBI is one of the most common indications for hospitalization among children and is often associated with important morbidity and mortality [2]. CT is the reference standard for emergently diagnosing TBI although some brain injuries are not seen on CT [3]. Children who

Manuscript received: $6^{\text {th }}$ February 2017

Reviewed: $14^{\text {th }}$ February 2017

Author Corrected: $20^{\text {th }}$ February 2017

Accepted for Publication: $28^{\text {th }}$ February 2017 sustain TBI are at high risk for problems in behaviour, adaptive functioning and educational performance [4]. Most of these cases are considered to be mild. Although more severe cases may cause greater levels of dysfunction, mild TBI occurs in much larger numbers and its consequences are not trivial [5]. Current literature (ie.) studies on learning, memory, cognitive functioning and academic achievement suggests that deficits persists long term in children and adolescents who are severely injured, whereas children and adolescents with mild to moderate TBI showed fewer deficits and greater recovery [6].

Falls were the most common cause of injury (58\%) in all ages and most predominant in the under two year old age group, followed by cycling and pedestrians involved in road traffic accidents in the group of children aged over six years old [7]. Falling and being struck by an automobile were the 2 most common causes of head injuries in children [8]. Blunt head 
Original Research Article

trauma is very common in children and can result in a skull fracture in upto 30\% [9]. Facial injuries were one of the most common concomitant injuries, especially in the patients aged 1 and 4 years [10].

\section{Materials and Methods}

This is a hospital based, retrospective, descriptive study, of children aged 3 months to 15 years of age admitted and treated in pediatric department from October 2013December 2016 in Velammal Medical College, Madurai.

The patients needed for this study were identified by reviewing our department nominal register by the diagnosis as head injury /Accidental fall.

\section{Inclusion Criteria}

- Children of 3 months to 15 years of presenting within 24 hours of head injury, to the pediatric department of velammal medical college.

- Complete patient information along with neuroimaging report in the medical records.

\section{Exclusion Criteria:}

- Children with polytrauma, incomplete information in medical records.

- Head injury children with pre-existing neurological disorders, bleeding disorders, previous history of traumatic brain injury, neuro-imaging done outside before admission.

The following data was collected from the medical records department, about the children included in this study.

* Age, sex, demographic data, mechanism of head injury, clinical profile of the patient at admission.

* Severity of head injury was assessed using glascow coma scale.

* Soft tissue injury to the scalp \& face, duration of hospitalization, surgical intervention if any and neuroimaging findings were noted for all patients.

* Outcome was studied as full recovery, partial recovery, death, against medical advice.

\section{Results}

Out of the 77 children admitted with head injury from October 2013-December 2016 in pediatric department of Velammel Medical College, 24 children were excluded. The reasons being, 5 children had pre-existing neurological problems, 9 children had sustained polytrauma involving other organs also.

About 7 children had incomplete information in medical records. Information related to 3 children could not be traced.

As about 53 children who fulfilled the inclusion criteria were studied and the results were analyzed as below.

Table-1: Demographic Data.

\begin{tabular}{|l|c|c|}
\hline Demographic Data & $\begin{array}{c}\text { No. } \\
(\mathbf{N}=\mathbf{5 3})\end{array}$ & Percentage \\
\hline Gender & 32 & 60.3 \\
$\bullet$ Male & 21 & 39.6 \\
• Female & 17 & 32 \\
\hline Age group & 22 & 41.5 \\
• 3 months-5 years & 14 & 26.4 \\
\hline - 5-10 years & & \\
\hline $10-15$ years & & \\
\hline
\end{tabular}

In table-1, it was seen that, out 53 children studied, male children 32 (60.3\%), female 21 (39.6\%). Maximum numbers of head injury children were seen among 5-10 years of age- $22(41.5 \%)$. 
Table-2: Mechanism of head injury.

\begin{tabular}{|l|c|c|}
\hline Mechanism & $\begin{array}{c}\text { No. } \\
(\mathbf{N}=\mathbf{5 3})\end{array}$ & Percentage \\
\hline \multicolumn{1}{|c|}{ RTA } & 28 & 52.8 \\
- Motor Vehicle Accident & 19 & 35.8 \\
- Injury to Pedestrian & 3 & 5.6 \\
- Car/Bus Accident & 4 & 7.5 \\
- Cycling & 2 & 3.7 \\
\hline Fall & & \\
& 25 & 40.7 \\
- From stairs & & 13.2 \\
- From height & 7 & 7.5 \\
- From Cot & 4 & 11.8 \\
- From mother's lap & 6 & 1.8 \\
- From Camel Ride & 1 & 1.8 \\
- From ground while walking & 1 & 11.8 \\
\hline
\end{tabular}

According to table-2, it was seen that, $28(52.8 \%)$ had head injury due to road traffic accident. Out of which motor vehicle accident was the most common cause, seen in 19 (35.8\%), Car/Bus accident 4 (7.5\%). In rest of the 25 children $(47.1 \%)$, head injury was due fall.

Table-3: Clinical Profile of head injury children.

\begin{tabular}{|l|c|c|}
\hline Symptoms/Signs & Number (n= 53) & Percentage \\
\hline Vomiting & 31 & 58.4 \\
\hline Obvious scalp/face injury & 22 & 41.5 \\
\hline Headache & 20 & 37.7 \\
\hline Altered sensorium & 15 & 28.3 \\
\hline Raised ICT & 11 & 20.7 \\
\hline Ear/Nose Bleed & 6 & 11.3 \\
\hline Eye Ecchymosis & 4 & 7.5 \\
\hline Nausea & 2 & 3.7 \\
\hline Seizures & 1 & 1.8 \\
\hline Pupil asymmetry & 1 & 71.8 \\
\hline GCS 13-15 (mild) & 38 & 16.9 \\
\hline $9-12$ (mod) & 9 & 11.3 \\
\hline$\leq 8$ (severe) & 6 & \\
\hline
\end{tabular}

According to table -3 , it was seen that the most common symptom after sustaining head injury was vomiting 31 (58.4\%), followed by obvious injuries to the scalp and face in $22(41.5 \%)$, headache in $20(37.7 \%)$ of children, altered sensorium in the form of drowsiness/agitation in $15(28.3 \%)$. Other features observed raised ICT in 11 children $(20.7 \%)$, ear/nose bleed in $6(11.3 \%)$, eye ecchymosis in $4(7.5 \%)$, nausea in $2(3.7 \%)$. Seizures and pupillary asymmetry due to direct third nerve injury was seen in one child each $(1.8 \%)$.

The severity of head injury was assessed, using glascow coma scale. It was seen that 38 of them (71.6\%) had mild head injury, $9(16.9 \%)$ had moderate head injury, $6(11.3 \%)$ had severe head injury. 
Table-4: Neuroimaging Analysis.

\begin{tabular}{|c|c|c|}
\hline CT-scan head & $\begin{array}{c}\text { Number } \\
(n=53)\end{array}$ & Percentage \\
\hline Brain Injury & 37 & 69.8 \\
\hline - Extra dural hematoma & 4 & 7.5 \\
\hline - Subdural hematoma & 5 & 9.4 \\
\hline - Sub arachnoid hemorrhage & 6 & 11.3 \\
\hline - Sub galeal bleed & 4 & 7.5 \\
\hline - frontal lobe contusion & 4 & 7.5 \\
\hline - parietal lobe contusion & 2 & 3.7 \\
\hline - Occipital lobe contusion & 3 & 5.6 \\
\hline - Midline shift & 2 & 3.7 \\
\hline Skull Bone Fracture & 26 & 49 \\
\hline - Frontal Bone & 6 & 11.3 \\
\hline - Temporal Bone & 3 & 5.6 \\
\hline - Parietal Bone & 4 & 7.5 \\
\hline - Occipital Bone & 5 & 9.4 \\
\hline - Base of Skull fracture & 1 & 1.8 \\
\hline - Multiple skull bone fracture & 7 & 13.2 \\
\hline Facial Bone Fractures & 9 & 16.9 \\
\hline - Nasal Bone & 3 & 5.6 \\
\hline - Condyle of Mandible & 2 & 3.7 \\
\hline - Orbital plate & 2 & 3.7 \\
\hline - Dentoalveolar-fracture & 1 & 1.8 \\
\hline - Hemosinus & 1 & 1.8 \\
\hline
\end{tabular}

According to table 4 , it was seen that 37 children (69.8\%) had neuroimaging findings related to brain injury. The most common was subarachnoid hemorrhage 6 children (11.3\%), followed by subdural hematoma in 5 of them $(9.4 \%)$ and extradural hematoma 4 (7.5\%) of them. Sub galeal bleed was seen in 4 (7.5\%) of children. Brain contusion was seen in 9 (16.9\%). Most common was frontal lobe contusion 4 (7.5\%), followed by occipital lobe $3(5.6 \%)$ and parietal lobe contusion $2(3.7 \%)$ of children. Midline shift was seen in 2 of them (3.7\%).

Table-5: Classification of cases based on management.

\begin{tabular}{|c|c|c|}
\hline Management of cases & Number $(n=53)$ & Percentage \\
\hline $\begin{array}{l}\text { Medical Management Pediatric ward } \\
\text { Intensive Care Unit } \\
\text { - Severe head injury for Ventilation } \\
\text { - For postoperative care } \\
\text { - For monitoring moderate head injury cases } \\
\text { - Multiple Skull Bone fracture } \\
\text { - Mild head injury \& Parental anxiety. }\end{array}$ & $\begin{array}{c}18 \\
35 \\
6 \\
8 \\
9 \\
7 \\
5\end{array}$ & $\begin{array}{c}33.9 \\
66 \\
11.3 \\
15 \\
16.9 \\
13.2 \\
9.4\end{array}$ \\
\hline $\begin{array}{l}\text { Surgical Management } \\
\text { - Suturing of Scalp laceration } \\
\text { - Open Reduction and internal fixation of Nasal Bone fracture } \\
\text { - Pop splinting of nasal bone fracture } \\
\text { - Cap splinting of Dento- alveolar fracture } \\
\text { - Elevation of depressed frontal bone fracture } \\
\text { - Wound debridement }\end{array}$ & $\begin{array}{l}8 \\
3 \\
1 \\
1 \\
1 \\
1 \\
1\end{array}$ & $\begin{array}{c}15 \\
5.6 \\
1.8 \\
1.8 \\
1.8 \\
1.8 \\
1.8\end{array}$ \\
\hline
\end{tabular}


Skull bone fractures were noticed in 26 children (49\%). Most common was frontal bone fracture 6 (11.3\%), followed by occipital bone 5 (9.4\%), parietal bone 4 (7.5\%) and temporal bone $3(5.6 \%)$. Base of skull fracture was seen in 1 child $(1.8 \%)$. Fractures involving two or more skull bone was seen in 7 of them $(13.2 \%)$.

Facial bone fractures were seen in 11 children (20.7\%). Nasal bone fracture was most common, seen in 3 children (5.6\%), fracture involving orbital plate and condyle of mandible was seen in 2 children each (3.7\%). Dento alveolar fracture and hemosinus was seen in $(1.8 \%)$.

According to table -5 out of 53 children, 18 of them (33.9\%) were admitted in paediatric ward with mild head injury. As about 35 children (66\%) were admitted to intensive care unit. The reasons being severe head injury needing ventilation 6 $(11.3 \%), 8(15 \%)$ needing post operative care after surgical intervention, 9 children $(16.9 \%)$ with moderate head injury for intensive monitoring, $7(13.2 \%)$ had multiple skull bone fractures, $5(9.4 \%)$ had mild head injury with parental request for intensive care.

Surgical intervention was needed in 8 children (15\%). Out of which, 3(5.6\%) needed suturing of scalp laceration, 1 $(1.8 \%)$ for scalp wound debridement, 1 child (1.8\%) for elevation of depressed frontal bone fracture. Procedures like POP splinting and open reduction and internal fixation was done for nasal bone fractures in 2 children. Cap splinting was done for dento-alveolar fracture in one child. After surgical intervention, 8 children were shifted to pediatric intensive care unit for post operative care.

Table-6: Hospital stay and outcome.

\begin{tabular}{|l|c|c|}
\hline Hospitalization & $\mathbf{N = 5 3}$ & Percentage \\
\hline No. of Hospital days & & \\
$<5$ days & 33 & 62.2 \\
5-10 days & 15 & 28.3 \\
$>10$ days & 5 & 9.4 \\
\hline Out come & & \\
- Full Recovery & 46 & 86.7 \\
- Partial Recovery (Focal neurological Deficit / cognitive deficit) & & \\
* Ventilated cases & 2 & 3.7 \\
- Third nerve palsy & 1 & 1.8 \\
- Death (Ventilated Cases) & 2 & 3.7 \\
\hline
\end{tabular}

According to table -6 , it was seen that, out of 53 children, 33 of them (62.2\%) were hospitalized for less than 5 days. All of them were had mild head injury, 15 (28.3\%) were hospitalized for 5 to 10 days, 5 children (9.4\%) were hospitalized for more than 10 days.

The outcome of 53 children were as follows, $46(86.7 \%)$ fully recovered, 3 of them $(5.6 \%)$ had partial recovery at the time of discharge. Out of which, 2 of them were ventilated children, with mild cognitive deficit and one of them had visual defect due to direct third nerve injury in recovery stage. As about 2 (3.7\%) of ventilated children for severe head injury were declared dead and 2 (3.7\%) of ventilated children for severe head injury, went against medical advice.

\section{Discussion}

It was seen that in our study, out of 53 children, males $32(60.3 \%)$ out numbered females 21 (39.6\%). Similar findings were reported by western authors in which incidence of head injury in males were $56 \%$ compared to females $44 \%$ [7]. The commonest age group affected in our study was $5-10$ years of age 22 children (41.5\%) compared to other age groups 3 months- 5 years 17
$(32 \%)$. In contrast it was seen that children less than 6 years of age formed $70 \%$ of the sample [7]. Our study, noted that road traffic accident was the most common cause of head injury in 28 children (52.8\%), followed by accidental fall in $25(47.1 \%)$ of them. Similar findings were noted by western author [7] .But accidental fall was observed as the most cause of head 
injury in children in many studies $[15,16]$. The most common clinical symptom noted after head injury in children was vomiting 31 (58.4\%) followed by obvious injuries to scalp the face $22(41.5 \%)$, headache 20 (37.7\%), altered sensorium (15) $28.3 \%$ of children. In a study done by western author, vomiting was seen in $50 \%$, followed by loss of consciousness in $14.8 \%$ of children. In our study mild head injury 38 children $(71.6 \%)$ out numbered moderate $9(16.9 \%)$ and severe head injury children $6(11.3 \%)$. Similar findings was noted by many authors in various studies related to head injury in children $[3,7]$.

It was observed that sub arachnoid hemorrhage was present in 6 children $(11.3 \%)$, followed by subdural hemorrhage $5(9.4 \%)$, extra dural hemorrhage 4 (7.5\%). In a study done by Indian author, it was observed that, extra axial bleed was observed in $35.9 \%$ of children, followed by subarachnoid hemorrhage in $33 \%$ of children [11].

Frontal lobe contusion 4 (7.5\%) was most commonly noted followed by occipital lobe contusion 3 children $(5.6 \%)$, parietal lobe contusion in $2(3.7 \%)$ of children. Similar findings were observed by Indian author [11].

In our study, nasal bone fracture was the most common facial bone fracture noted in $3(5.6 \%)$ of children, followed by fracture of condyle of mandible $3(5.6 \%)$, which was similar to other study [17]. In contrast to this, in a study done by Indian author it was noted that injuries to the eyes and lips were most common facial injury followed by nasal fracture [10].

It was observed that in our study, 35 children (66\%) needed intensive care. 18 children (33.9\%) needed ward admission. In our study, 8 out of 53 children needed surgical intervention. It was noted that $33(62.2 \%)$ of them needed hospitalization for less than 5 days. 15 $(28.3 \%)$ of them had a hospital stay of 5 to 10 days

Only 5 children $(9.4 \%)$ were in hospital for more than 10 days. Out of which, 2 of them, were severe head injury- ventilated, who partially recovered and discharged home, 3 of them needed post operative care, after surgical intervention. The above findings were similar to other studies $[7,13]$.

In our study, it was noted that $46(86.7 \%)$ of them had full recovery, partial recovery in $3(5.6 \%)$, death in 2 $(3.7 \%)$. Similar findings were reported by other authors [14].

\section{Conclusion}

Road traffic accident is the predominant cause of head injury in children. Stringent measures to follow traffic safety rules has be implemented, such a zebra crossing for pedestrian, helmet for motor vehicle occupant also. Early intervention, aggressive medical and surgical management is advised, when needed particularly for moderate and severe cases of head injury in children to reduce morbidity and mortality. Parental guidance is advised to avoid accidental falls at home.

Acknowledgement- I thank all the MRD staffs of Velammal Medical College, for helping me in collection of patient information from medical records for this study

\section{Abbreviations}

TBI - Traumatic brain injury, MRD-Medical records department, POP- Plaster of paris.

Funding: Nil, Conflict of interest: None initiated, Perission from IRB: Yes

\section{References}

1. Murgio A. Epidemiology of traumatic brain injury in children. Revista Espanola de Neuropsicologia 5, (2003); 2:137-161.

2. Ghizoni E, Ade FM, Baracat EC, Joaquim AF, Fraga GP, Rizoli S, etal. Indications for head computed tomography in children with mild traumatic brain injury. Rev Col Bras Cir 2013;Nov-Dec;40(6):515-9.

3 Kuppermann N, Holmes JF, Dayan PS, Hoyle JD, Atabaki SM, Holubkov R, etal. Identification of children at very low risk of clinically important brain injuries after head trauma: a prospective cohort study. Lancet. 2009 Oct 3;374(9696):1160-70. doi: 10.1016/ S0140-6736(09)61558-0. Epub 2009 Sep 14.

4. Taylor HG, Yeates KO, Wade SL, Drotar D, Stancin T, Minich N. A prospective study of short- and longterm outcomes after traumatic brain injury in children: behavior and achievement. Neuropsychology. 2002 Jan; 16(1):15-27.

5. Max JE, Friedman K, Wilde EA, Bigler ED, Hanten $\mathrm{G}$, Schachar RJ, etal. Psychiatric disorders in children and adolescents 24 months after mild traumatic brain injury. J Neuropsychiatry Clin Neurosci 2015;27(2): 112-120. https://doi:10.1176/appi.neuropsych.13080190 
6. Jurado EA, Paulsen JS, Ehly S, Max JE. Traumatic Brain Injury in Children and Adolescents: Academic and Intellectual Outcomes Following Injury. Exceptionality 2006;14(3): 125-140.

7. Maw A, Tasker R, Bateman A, Gracey F, Kieta F, Bower R, etal. Mild and moderate traumatic brain injury in childhood - who gets admitted?. Pediatric neurology ACNR 2011;11( 5):14-16

8. Harwood-Nash DC, Hendrick EB, Hudson AR. The significance of skull fractures in children. Radiology 1971;Oct 101(1):151-156. http://pubs.rsna.org/doi/pdf/ $10.1148 / 101.1 .151$

9. Arneitz C, Sinzig M, Fasching G. Diagnostic and Clinical Management of Skull Fractures in Children. J Clin Imaging Sci. 2016;6:47.

10. Kapapa T, Kapapa M, Posovszky C, Gulke J, Konig R, Woischneck D, Wirtz CR, Pala A. Paediatric Head Injury: The Incidence of Multiple Injuries. Journal of Behavioral and Brain Science. 2016 Jun;6(6):254-267.https://dx.doi.org/10.4236/jbbs. 2016. 66026.

11. Kumar M, Hussain M, Saeed S, Huda MF, Usmani JA. Head injuries sustained by children due to fall from height: A comprehensive study. J Indian Acad Forensic Med.Oct-Dec 2013; 35 (4 ):305-307.
12. Erhasin Y, Mutluer S, Mirzai H, Palali I. Pediatric depressed skull fractures: analysis of 530 cases. Childs Nerv Syst 1996 Jun; 12( 6): 323-31.

13. Morris KP, Forsyth RJ, Parslow RC, Taskar RC, Hawley CA. Intracranial pressure complicating severe traumatic brain injury in children:monitoring and management. Intensive care med 2006 Oct;32(10): 1606-12.https://doi:10.1007/s00134-006-0285-4.

14. Park SH, Cho B, Oh SM. Head injuries from falls in preschool children. Yonsei Med J 2004;45 (2): 229-232.

15. Ibrahim NG, Wood J, Margulies SS, Christian CW. Influence of age and fall type on head injuries in infants and toddlers. Int. J. Devl. Neurosci 2012 May; 30(3):201-6. doi:10.1016/j.ijdevneu.2011.10.007

16. Tascu A, Pascal C, Lencean M, Gorgan MR. Aggressive or conservative management in extradural hematomas in children-a challenging neurosurgical choice. Romanian Neurosurgery 2014;4: 384-393. https: //doi.org/10.2478/romneu-2014-0054

17. Cole P, Kaufman Y, Hollier LH. Managing the pediatric facial fracture. Craniomaxillofac Trauma Reconstr. 2009 May;2(2):77-83.

\section{How to cite this article?}

Maheswari K. Clinico-etiological profile and outcome of traumatic head injury in children- a tertiary care experience. $\mathbf{J}$ PediatrRes. 2017; 4(02):195-201.doi:10.17511/ijpr.2017.102.20. 